\title{
A Woman of No Importance?: Elizabeth Workman's Collection of Impressionist and Post-Impressionist Art in Context
}

\author{
Frances Fowle
}

The late nineteenth and early twentieth centuries witnessed the rise of the mercantile classes in Britain and the creation of a new industrial elite. Concurrently, there was a shift towards increasing independence for women and a raised awareness of women's rights, as crucial changes were enacted in the laws concerning marriage and ownership of property. In the sphere of collecting, women became major promoters of modern art, even if they were less in evidence than their female counterparts in the USA or their male equivalents in Britain. It was not until 1951, for example, that the National Museum of Wales was enriched by the Davies sisters' collection, even though they began collecting before the First World War. Historically, more credit has been given to English and Irish male philanthropists, such as Sir Samuel Courtauld and Sir Hugh Lane, than to the women who played a key role in the early accessioning of Impressionism in British museums and galleries. These included not only the Davies sisters in Wales, but collectors such as Anne Kessler in England and Rosalind Maitland and Isabel M. Traill in Edinburgh. ${ }^{1}$ Indeed, there are numerous women, often the wives of prominent businessmen, whose roles as tastemakers have been completely ignored: either because their independence of thought has been credited to an agent or spouse; or because their husband controlled the finances and their name has never been recorded in receipts or dealer stock books. The focus of this article is one such collector, Elizabeth Workman, whose role as a major British collector of Impressionism has been, at best, confused with that of her husband and, at worst, exploited by the latter for financial gain.

Elizabeth Russell Workman (1874-1962) (Fig. 1), as well as being a celebrated master yachtsman and a mother of four, was one of the most enlightened art collectors of her generation. In the 1920 she and her husband Robert Alfred Workman (1872-1948) lived at 3 Seamore Place in an exclusive part of London's Mayfair. She was captured on canvas by several

${ }^{1}$ Alan Bowness, The Mrs A. F. Kessler Bequest to the Tate Gallery (London: Tate Gallery, 1984); David Baxandall and Colin Thompson, Nineteenth and Twentieth Century French Paintings: The Maitland Gift and Related Pictures (Edinburgh: National Gallery of Scotland, 1963); Hugh Brigstocke, The Richmond-Traill Collection (Edinburgh: National Gallery of Scotland, 1980). 


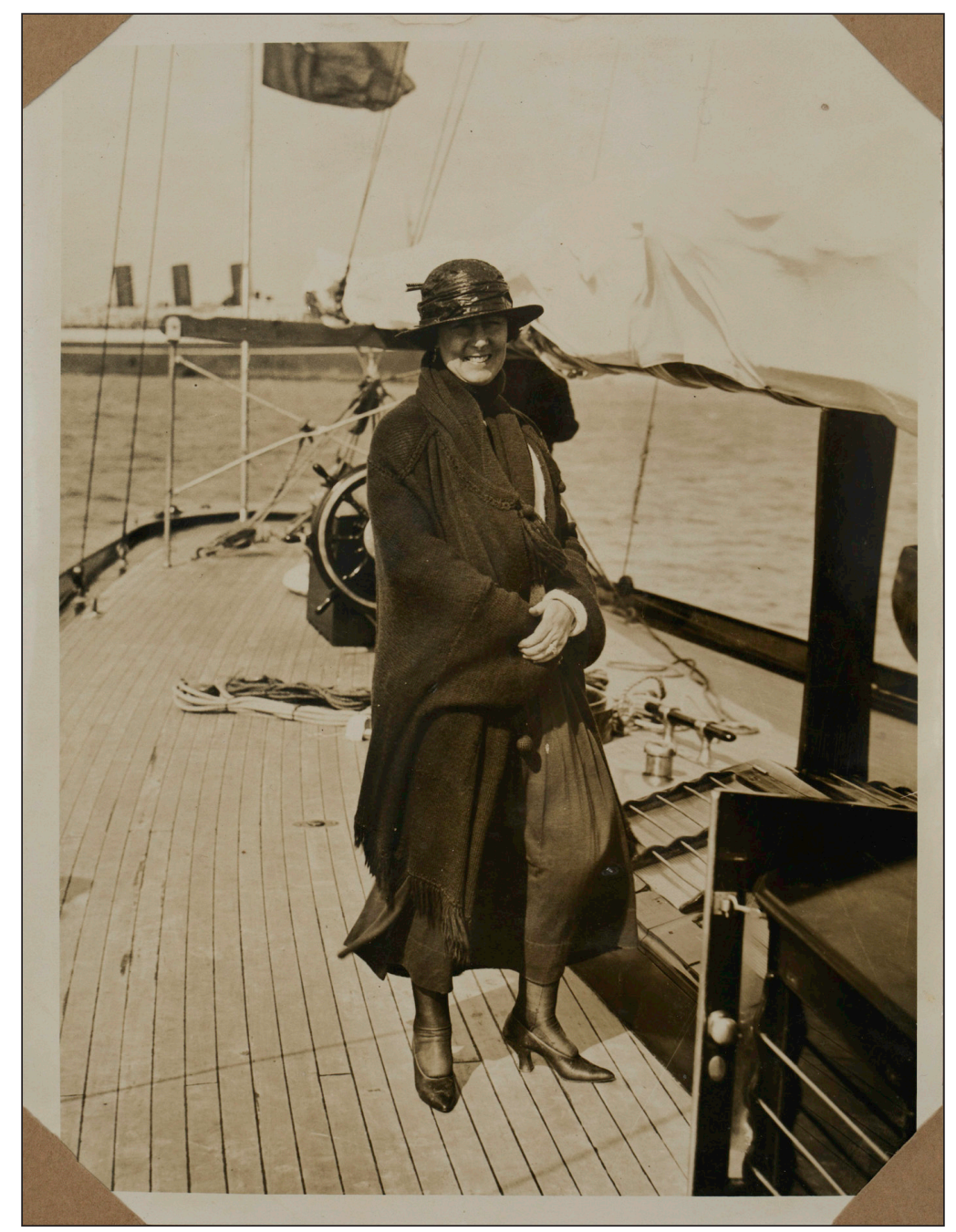

Fig. 1: Elizabeth Workman on board Nyria, c. 1920. Photo by kind permission of the Janson family.

leading artists of the period, not least Percy Wyndham Lewis, who in 1923 described her as 'one of the only people in England to understand French painting'. ${ }^{2}$ Elizabeth began collecting French Impressionism well before better-known contemporaries such as Courtauld, and in several ways she was more adventurous in her tastes. And yet today not only is her important collection of Impressionist and post-Impressionist art largely forgotten, Elizabeth Workman herself remains invisible, an unidentified

\footnotetext{
${ }^{2}$ Wyndham Lewis, Blasting \& Bombardiering, 2nd rev. edn (Berkeley: University of California Press, 1967), p. 229.
} 
figure, occasionally listed in provenance histories, and more often than not under her husband's name. Despite this, it was undoubtedly she and not he who was the more enlightened collector for, as the Scottish art dealer A. J. McNeill Reid once put it, although Robert Workman held the purse strings, 'it was $[\ldots]$ Mrs Workman who had the taste.'3

For reasons which will become clear, the Workman collection was dispersed in the late 1920 os and 1930s. As a result, many of the more important paintings were absorbed by major international museums, such as the National Gallery of Art, Washington, the Metropolitan Museum of Art, New York, and the State Hermitage Museum, St Petersburg. Elizabeth assembled the collection almost entirely through the assistance of three British dealers: Glasgow-based Alexander Reid, his son A. J. McNeill Reid, and their London partner Ernest Lefèvre. However, no diaries and virtually no personal correspondence to or from Elizabeth have survived and it is difficult to form an opinion of her motivations for buying or of any philanthropic intentions she might have had. In many ways, therefore, her collection should be viewed as a reflection of the pioneering efforts of Reid and Lefèvre to promote modern French painting - and contemporary Scottish art - in the early years of the twentieth century.

While efforts have been made by scholars in the past to fill in the gaps, the full extent and importance of the Workman collection has not been properly recognized, while Elizabeth herself remains a two-dimensional figure, variously described as 'E. R. Workman', 'Mrs R. A. Workman', and even 'R. E. Workman'. The only essay on the collection was published in Apollo in 1926 by the artist and curator James Bolivar Manson, who painted Elizabeth's portrait in the same year. ${ }^{4}$ Manson ascribes ownership of the collection to the Workmans as a couple and, since he discusses only the more important pictures that were then hanging in the Workmans' London house, the essay tells an incomplete story. Research for this article, therefore, has involved the painstaking identification of works itemized in the Alex Reid \& Lefèvre Gallery stock books, now housed in the Tate Archive, as well as those listed in the collection sale catalogues. Drawing on these sources, and on new material in the family archive, this article aims to create a more rounded picture of this 'invisible' woman and her collection, and to reassess her importance as a British collector of the early twentieth century. ${ }^{5}$

3 Letter from A. J. McNeill Reid to Douglas Cooper, 9 April 1953, Los Angeles, Getty Research Institute, Douglas Cooper Papers, Box 14, Folder 5. Subsequent references to this letter will be cited parenthetically within the text as 'McNeill Reid 1953 '.

${ }^{4}$ J. B. Manson, 'The Workman Collection: Modern Foreign Art', Apollo, March 1926, pp. 139-44.

5 I am profoundly grateful to Bella Janson, Elizabeth Workman's great-granddaughter, for her generosity in sharing photographs, cuttings, and other archival 


\section{Women collectors of Impressionism in Britain}

Art history has focused to date on the important role of dealers like Paul Durand-Ruel in bringing Impressionism to Britain and winning (exclusively male) clients such as Henry Hill of Brighton and John Duncan of Benmore among the rising classes. ${ }^{6}$ However, as this article argues, in many cases this taste was shared by lesser-known female collectors, often living in the shadow of their husbands, but who nevertheless provide a useful framework for Elizabeth Workman's collecting practice.

Among the earliest women collectors of Impressionism in Britain were Ellen Sickert (née Cobden, 1848-1914) and her sister Jane (1851-1947). Ellen was the wife of the artist Walter Sickert and they were all close friends of Degas, especially from 1885 , when the latter painted Ellen's portrait. ${ }^{7}$ Ellen confessed to their artist friend Jacques-Émile Blanche that Degas's work 'haunted' their imaginations. In 1886 she and her husband acquired their first two works, the Swaying Dancer of 1877-79 (Museo Thyssen-Bornemisza, Madrid) and Mlle Bécat aux Ambassadeurs (private collection, L121R). Three years later, Sickert bought the highly experimental Rehearsal of the Ballet on Stage (c. 1874, Metropolitan Museum of Art, New York) as a gift for Ellen.

In the early 1890 , for financial reasons, the Sickerts shared a house with Jane, who subsequently became the owner of both the Swaying Dancer and Mlle Bécat. ${ }^{8}$ They continued to add to their collection and, in 1902, Ellen

material related to Mrs Workman. See also, Frances Fowle, 'Alexander Reid in Context: Collecting and Dealing in Scotland in the Late $19^{\text {th }}$ and Early $20^{\text {th }}$ Centuries' (unpublished doctoral thesis, University of Edinburgh, 1994); Madeleine Korn, 'Collecting Modern Foreign Art in Britain before the Second World War' (unpublished doctoral thesis, University of Reading, 2001); Madeleine Korn, 'Collecting Paintings by Matisse and by Picasso in Britain before the Second World War', Fournal of the History of Collections, 16 (2004), 111-29; Martin Bailey with Frances Fowle, Van Gogh and Britain: Pioneer Collectors (Edinburgh: National Galleries of Scotland, 2006), pp. 40, 84, 129; Frances Fowle, Impressionism and Scotland (Edinburgh: National Galleries of Scotland, 2008), pp. 71, 86-87, 89, 136; Frances Fowle, Van Gogh's Twin: The Scottish Art Dealer Alexander Reid 1854-1928 (Edinburgh: National Galleries of Scotland, 2010), pp. 96, 111-12, 122, 129-32, 134, 142-43.

${ }^{6}$ Inventing Impressionism: Paul Durand-Ruel and the Modern Art Market, ed. by Sylvie Patry (London: National Gallery, 2015); Anne Robbins, 'Monet, Pissarro and Fellow French Painters in London, 1870-71', in Impressionists in London: French Artists in Exile 1870-1904, ed. by Caroline Corbeau-Parsons (London: Tate Gallery, 2018), pp. 5779; Andrew McDonald Watson, 'James Duncan of Benmore, the First Owner of Renoir's Bay of Naples (Morning)', Metropolitan Museum Fournal, 43 (2008), 195-200.

7 On Jane Cobden and the Sickerts' relationship with Degas, see Anna Gruetzner Robins, 'Sickert's Campaign for Degas', in Anna Gruetzner Robins and Richard Thomson, Degas, Sickert and Toulouse-Lautrec: London and Paris 1870-1910 (London: Tate Gallery, 2006), pp. 58-66.

${ }^{8}$ Madeleine Korn, 'Exhibitions of Modern French Art and Their Influence on Collectors in Britain 1870-1918: The Davies Sisters in Context', fournal of the History of Collections, 16 (2004), 191-218 (p. 214). 
and Sickert acquired Degas's Woman at a Window (Courtauld Institute), in part exchange for the Rehearsal. Like all these early purchases, this canvas shows the French artist at his most experimental, intent on capturing the effect of a woman's form silhouetted and slightly distorted against the light. It was clearly Ellen's, rather than her husband's acquisition, since after her death in 1914 it passed to her sister Anne Cobden-Sanderson (1853-1926).

Daughters of the British statesman and reformer Richard Cobden, the Cobden sisters were politically active and early proponents of women's rights, as well as passionate about art. (Anne was even arrested in 1906 for participating in suffragette activities.) Jane's husband was the publisher Thomas Fisher Unwin, who not only published avant-garde works by the likes of Ibsen, Nietzsche, and H. G. Wells, but acquired three works by Van Gogh in Paris shortly after the couple married in 1892. Was it in fact Jane, rather than her husband, who was behind these purchases?9

The Cobden sisters had very different profiles from most female collectors in Britain, but they shared their espousal of the feminist cause with, for example, the American philanthropist and suffragist Louisine Havemeyer (1855-1929). In 1875, when she was still unmarried, Havemeyer bought her first works by Degas and Monet, advised by Mary Cassatt, and in 1929 she left her important collection of Impressionist painting to the Metropolitan Museum of Art, New York. Cassatt, along with Lilla Cabot Perry, encouraged other women collectors, including Sarah Choate Spears in Boston; while the agent Sara Hallowell inspired Bertha Palmer (1849-1918) in Chicago to build up a significant collection of paintings by Degas, Monet, Renoir, and Pissarro in the early $1890{ }^{10}{ }^{10}$ Unlike Ellen Sickert, Palmer made these purchases independently and kept a careful account of each transaction, ${ }^{11}$ despite which Durand-Ruel appears to have logged all sales in the name of her husband, Potter Palmer. ${ }^{12}$ Similarly, Hallowell's correspondence was always addressed to Mr Palmer, rather than his wife, suggesting that he had ultimate control of the finances.

9 Fisher Unwin bought three works from Père Tanguy's shop in Paris in 1893 (Bailey, Van Gogh and Britain, pp. 20, 128).

${ }^{10}$ Erica E. Hirshler, "Helping "Fine Things Across the Atlantic": Mary Cassatt and Art Collecting in the United States', in Mary Cassatt: Modern Woman, ed. by Judith A. Barter (Chicago: Art Institute of Chicago, 1998), pp. 177-211; Erica E. Hirshler, Impressionism Abroad: Boston and French Painting (London: Royal Academy Publishing, 2005), pp. 17-42; Carolyn Kinder Carr, Sara Tyson Hallowell: Pioneer Curator and Art Adviser in the Golden Age (Washington DC: Smithsonian Institution Scholarly Press, 2019).

${ }^{11}$ Richard R. Brettell, 'Monet's Haystacks Reconsidered', Art Institute of Chicago Museum Studies, 11 (1984), 4-21 (pp. 19 and 21, n. 19).

${ }_{12}$ For example, Mrs Palmer's Renoir, Acrobats at the Cirque Fernando of 1879, was recorded in Durand-Ruel's Paris stock book 1891 (no. 319) as: 'Vendu [...] à Potter Palmer le 11 mai 1892 pour 8000 francs.' Art Institute of Chicago, Durand-Ruel Archives to the Art Institute of Chicago, 5 October 2010, object file. 
The financial dependency of married women collectors is something that deserves further research and will be explored later in this article in relation to Elizabeth Workman.

Encouraged by the developing taste for Impressionism in Britain, and of later significance to Elizabeth, it was around this period that the Glasgow dealer Alexander Reid opened his Glasgow gallery, known as La Société des Beaux-Arts. Established in 1889, it sold works by Degas, Manet, Monet, Sisley, and Pissarro to a number of Scottish merchants and industrialists. ${ }^{13}$ Of these the most significant was Sir William Burrell, who acquired at least twenty-four works by Degas during his lifetime, as well as pictures by Sisley, Renoir, Pissarro, Manet, and Cézanne. ${ }^{14}$

Reid made his earliest sales of Impressionist pictures in 1892, but it was not until later in the decade that British women collectors began to focus more consistently on modern French art. Perhaps unsurprisingly, most of the earliest purchases were made by female artists, or by women who, like the Cobden sisters, had close artistic connections, or by society hostesses who enjoyed the company of artists. An important moment may have been the bequest of Gustave Caillebotte's collection to the French State. In 1896 around forty paintings by Degas, Manet, Monet, Renoir, Sisley, Pissarro, and Cézanne went on public display at the Musée du Luxembourg, attracting the attention of visitors to the city. In the same year, while they were living in Paris, the painter Esther Sutro (1869-1934), accompanied by her husband the playwright Alfred Sutro (1863-1933), bought Van Gogh's Interior of a Restaurant (private collection). Encouraged by the French Nabis artist Édouard Vuillard, the couple acquired the painting from the dealer Ambroise Vollard for only 300 francs (around £12). Esther cherished her purchase and kept it in her collection until her death. ${ }^{15}$

Another woman collector with British connections was the painter Romaine Brooks (1874-1970), the American wife of the English pianist and classical scholar John Ellingham Brooks. By 1905 she had acquired Degas's Avant le lever du rideau (Wadsworth Atheneum) a highly unusual work in pastel, which shows a performer (presumably an opera singer) and her dresser, viewed from above, putting the final touches to her costume on stage, before the curtain rises. Brooks's taste in art was guided less by her husband - theirs was a marriage of convenience, and by 1905 the couple had separated - than by her own artistic interests and by those of her lover,

13 On Alexander Reid and the early acquisition of Impressionism in Scotland, see Fowle, Van Gogh's Twin, and Fowle, Impressionism and Scotland.

${ }_{14}$ There are currently twenty-two works by Degas in the Burrell Collection, but another was sold and one left to Berwick Museum. See Vivien Hamilton and others, Drawn in Colour: Degas from the Burrell Collection (London: National Gallery, 2017).

15 Bailey, Van Gogh and Britain, pp. 20, 127. Alfred's elder brother Leopold Sutro, a wealthy rubber trader, also owned Van Gogh's Lane in Voyer d'Argenson Park at Asnières (Yale University Art Gallery, New Haven), acquired in 1928. 
the Princesse de Polignac, who regularly entertained the likes of Isadora Duncan, Jean Cocteau, and Monet. ${ }^{16}$

An overlooked figure of this period is Lady Alice Shaw-Stewart (1863-1942), who lived at Ardgowan, near Inverkip in Ayrshire. A member of the Oxford luminary group known as 'The Souls', she hosted literary salons in Scotland and regularly entertained artists, prime ministers, and members of the royal family. She was also one of the earliest British collectors to buy Impressionist art but, since these purchases were made in the name of her husband, Sir Hugh Shaw-Stewart (1854-1942), her own role as a collector, like many women of this period, has been all but forgotten. In 1905 she acquired Monet's The Cliffs near Dieppe of 1897 (W1463) at DurandRuel's Impressionist exhibition at the Grafton Galleries in $1905 \cdot{ }^{17}$ A closely framed, yet freely painted and atmospheric evocation of cliff, sea, and sky, it is one of a series of views looking down from the cliffs near the fashionable resort of Dieppe, taking in the sea and the sweep of coastline.

The most significant female supporter of the Impressionists in Britain before the First World War was Mary Hunter, née Smyth (1856-1933), a famous society hostess. Her sister was the composer Dame Ethel Smyth and Mary took great pleasure in supporting the arts. She was married to Charles Hunter, a Northumbrian coal-owner, and they divided their time between London and Hill Hall, near Epping, where they invited celebrities from the literary and artistic world. She befriended Monet in London and invited him and his wife Alice to Venice, to stay at her Gothic Palazzo Barbaro for two weeks in October 1908. As a result, Monet produced his dazzling series of atmospheric, almost Symbolist evocations of the floating city and Mary Hunter acquired his San Giorgio Maggiore by Troilight (private collection, W1750), an almost Whistlerian study in blue. ${ }^{18}$

Another society hostess, Emerald, Lady Cunard - American-born Maude Alice Burke (1872-1948) - made the most challenging purchase of the pre-war period: Gauguin's Nevermore of 1897 (Courtauld Institute). This enigmatic painting shows a naked Pahura, Gauguin's young 'vahine', lying on a bed. Even today such images court controversy, and no doubt appealed to the scandalous Emerald. While married to Lord Cunard, she was the lover and muse of the writer and critic George Moore and, before the war, the companion of Thomas Beecham. To her London salon she invited politicians and members of the aristocracy as well as musicians,

${ }^{16}$ Sylvia Kahan, Music's Modern Muse: A Life of Winnaretta Singer, Princesse de Polignac (Rochester: University of Rochester Press, 2005).

${ }_{17}$ Frances Fowle, 'Making Money out of Monet: Marketing Monet in Britain 18701905', in Monet and French Landscape: Vétheuil and Normandy, ed. by Frances Fowle (Edinburgh: National Galleries of Scotland, 2006), pp. 141-57 (p. 154).

${ }_{18}$ Korn notes that she also owned Les Ports de Yachts (unidentified) and La Côte Vieille à Conteleu (c. 1900), possibly by Blanche Monet (Korn, 'Exhibitions of Modern French Art', p. 215). 
artists, and writers; Lloyd George famously described her as 'a most dangerous woman'. ${ }^{19}$

As these few examples show, most female collectors in Britain before the First World War had strong artistic connections or pretensions. On the whole, they failed to take a sustained interest in Impressionism and were not concerned with building up a substantial collection. The exceptions were Gwendoline (1882-1951) and Margaret Davies (1884-1963), whose background could not have been more different from most of the examples discussed above. They were brought up as strict Calvinistic Methodists, yet they inherited an enormous fortune, which they spent on travel, art, and music. Their father died in 1898 leaving them around a million pounds, largely inherited from his own father, David Davies of Llandinam (18181890), who had made his fortune from the coal industry, as well as building railways and docks. ${ }^{20}$

The sisters began collecting in 1908, focusing initially on Turner, as well as Barbizon and Hague School painters, and moving on to Whistler and Monet. It was Gwendoline who built up the sisters' outstanding collection of late works by Monet, including several Venice paintings, a view of Charing Cross Bridge (1902), and three Water Lily paintings. Robert Meyrick has emphasized the role of the sisters' agent and adviser Hugh Blaker (1873-1937) in their purchases. ${ }^{21}$ By 1910, the year of Roger Fry's first groundbreaking post-Impressionist exhibition, Blaker was certainly familiar with the work of Manet, Monet, Gauguin, and Cézanne, but in terms of contemporary taste Gwendoline's purchases were far in advance of any other collector in Britain at that time, including Sir Hugh Lane, whose collection of Impressionist pictures was eventually split between London and Dublin. ${ }^{22}$ It was she, rather than Margaret, who made the really outstanding purchases, including Renoir's La Parisienne (1874), Cézanne's Still Life with Teapot (c. 1902-06), Van Gogh's Rain at Auvers (189o), and two important works by Manet. Margaret, by contrast, was much slower to appreciate the Impressionists, preferring Pissarro to any other artist.

After the war the sisters increased their expenditure, as well as venturing into Fauvism. In 1920 alone they bought eight works by Pissarro, six by Maurice de Vlaminck, four Cézannes, and one each by Paul Signac and André Derain. On Gwendoline's behalf Blaker offered three works by

19 Brian Masters, 'When Secrets Were Served with the Soup', The Times, 30 October 1982, p. 8.

${ }_{20}$ Mark Evans, 'The Davies Sisters of Llandinam and Impressionism for Wales, 1908-1923', Fournal of the History of Collections, 16 (2004), 219-53 (p. 221).

${ }_{21}^{21}$ Robert Meyrick, 'Hugh Blaker: Doing His Bit for the Moderns', Journal of the History of Collections, 16 (2004), 173-89.

${ }_{22}$ Evans, p. 222. On Lane, see Morna O'Neill, Hugh Lane: The Art Market and the Museum 1893-1915 (London: Yale University Press, 2018); and Hugh Lane: Founder of a Gallery of Modern Art for Ireland, ed. by Barbara Dawson (London: Scala, 2008). 
Cézanne on loan to the Tate, but - just as the National Gallery was halfhearted about Hugh Lane's generous bequest of Impressionist pictures in 1917 - the gallery was reluctant to accept them. It was only after all three were included in Roger Fry's 1922 exhibition of 'The French School of the Last Hundred Years' at the Burlington Fine Arts Club that the Tate agreed to take Midday, L'Estaque (Evans, p. 228). Later loans followed, but in the end the collection was left to Cardiff, rather than London. This was in part due to the Davies sisters' benevolence towards their home country, but was almost inevitably influenced by the London galleries' reticence towards Impressionism.

The impact of the Davies sisters' loans to galleries and exhibitions outside Wales cannot be underestimated. It is always said, for example, that Samuel Courtauld was inspired by the Davies's Cézannes at Fry's exhibition to build up his own collection of Impressionist and post-Impressionist art during the 1920s. He was also influenced by another woman with advanced tastes in art, his wife Elizabeth, whose role in the formation of the collection has only recently been acknowledged. Elizabeth Courtauld, née Kelsey (1875-1931) was passionate about music and art and, like many women collectors of this period, a constant guide and support to her husband's collecting activities. It was she, rather than Courtauld, who made the first two purchases for the collection: Renoir's magnificent Woman Tying Her Shoe and Jean Marchand's Saint-Paul, Côte d'Azur, which she spotted at London's newly established Independent Gallery in September 1922.23 As Karen Serres and Dimitri Salmon have recently observed, she not only initiated the collection, but introduced her husband to the dealer Percy Moore Turner, who became Courtauld's chief adviser. ${ }^{24}$ Nevertheless, her role is difficult to estimate since, like so many wives of collectors, her name is excluded from any financial transaction. The same problem arises with Elizabeth Workman, to whom the remainder of this article is devoted.

\section{The Workman collection}

Many of the issues raised above also apply to Elizabeth Workman and provide a useful framework in which to examine her collecting practice. Like Bertha Palmer and Elizabeth Courtauld, her activity as a collector has often been confused with that of her husband. For much of her life

\footnotetext{
${ }_{23}$ Dimitri Salmon, "Perhaps Courtauld's Most Trusted Adviser": Percy Moore Turner', in The Courtauld Collection: A Vision for Impressionism, ed. by Karen Serres (London: Fondation Louis Vuitton and Paul Holberton Publishing, 2019), p. 70. ${ }_{24}$ Karen Serres, 'Introduction: Samuel Courtauld, Champion of Impressionism', in The Courtauld Collection, ed. by Serres, pp. 1-13 (p. 3); and Salmon, p. 70. See also, Rachel Sloan, 'Renoir, "Woman Tying Her Shoe", in The Courtauld Collection, p. 178 .
} 
Mrs Workman's name rarely appeared in any stock book or daybook, while almost all correspondence was conducted by her husband. In addition, and unlike most prominent women collectors, her pictures were sold well before she had ceased collecting and it is virtually impossible to draw conclusions about her role as a philanthropist. What is certain, however, is the quality of the works she acquired, as well as her role as a supporter of the avant-garde.

Elizabeth was born Elizabeth Russell Allan on 23 November 1874 at 272 Bath Street, Glasgow, the eldest of six children. She had two brothers, James and Thomas, and three sisters, Ann, Margaret (Gretta), and Agnes. The girls were all highly educated and were among the first pupils at the all-girls boarding school St Leonard's in St Andrew's where the belief was that 'a girl should receive an education that is as good as her brother's, if not better'. ${ }^{25}$ Their father, James Allan, was a wealthy provision merchant from Helensburgh in Dunbartonshire. James and his wife Margaret (née Warren) were comfortably off and in the late 1890 os the family moved to Red Tower, an imposing red-brick house designed in 1898 by the well-known architect William Leiper. ${ }^{26}$

Elizabeth's future husband, Robert Workman, was also brought up in the west of Scotland. His parents, William Service Workman and Margaret (née Orr) lived at Dunluce House in the village of Dullater, Dunbartonshire and in 1900 acquired an elegant Glasgow town house designed by the Scottish architect John Gaff Gillespie at 12 University Gardens. ${ }^{27}$ William Workman was a director of the shipowners George Smith \& Sons, which was taken over by the Ellerman City Line in the 19oos. He originally came from Belfast, where Robert was born, and where he worked for the family shipping firm, Workman \& Clark.

Robert and Elizabeth Workman were married at Rhu, near Helensburgh, on 21 September $1900 .{ }^{28}$ Robert was then twenty-eight years old, living in Hampstead, and working in the City of London for the shipbroker's firm of Montgomerie \& Workman at 17 Gracechurch Street. ${ }^{29}$ Their first family home was at 61 Acacia Road, NW8, close to Regent's Park. It was here that their first child, Jean, was born in 1902, followed by Kirsteen in 1903 and Thomas in 1904. A fourth child, Bridget, was born much later in 1913. With both sets of parents living in Scotland the couple made frequent trips north, when they would stay either in Helensburgh or at the Workmans' Glasgow home. It was during these trips in the early 1900 s

${ }_{25}$ Crystal Clear: The Autobiographies of Sir Lawrence and Lady Bragg, ed. by A. M. Glazer and Patience Thomson (Oxford: Oxford University Press, 2015), p. 277.

${ }^{26}$ James Allan married Margaret Dunn Warren (1848-1946) in 1873.

${ }_{27}$ William's father William Orr Workman (of Davidson \& Workman) also lived at 12 University Gardens (Glasgow Post Office records).

${ }_{28}$ Extract from the Register of Marriages, Edinburgh, Scottish National Archives.

29 Robert Workman then lived at Westview, Worsley Road, Hampstead. 
that they began buying pictures at Alexander Reid's Glasgow gallery at 117 and 121 West George Street. Reid was without question the most innovative British dealer of this period. From 1886 to 1889 he had worked in Paris alongside Theo Van Gogh and had shared an apartment with the Van Gogh brothers. Both he and his son A. J. McNeill Reid were among the most enlightened dealers of their generation and exercised a significant influence on Elizabeth's collecting practices. Reid was a contemporary and supporter of the Glasgow Boys and, at least initially, he encouraged the couple to buy work by living Scottish artists such as E. A. Hornel, George Henry, David Gauld, Joseph Crawhall, Arthur Melville, and Robert Burns.

In 1953 McNeill Reid, recalling the gallery's relationship with the Workmans, asserted that the couple were both involved in building up the collection of Scottish pictures, as well as the occasional work by the Norwegian painter Frits Thaulow and the Dutch Impressionist George Hendrik Breitner. The more avant-garde French pictures were very much Elizabeth's domain, since she was 'always rather ahead of her time' (McNeill Reid 1953). Before the First World War, it is impossible to tell whether Robert or Elizabeth was guiding their choice of Scottish paintings, since the purchase books always list Robert as the buyer, while the later collection sales attribute the entire collection to Elizabeth. In 1903 it was possibly Robert who commissioned a portrait of Elizabeth by the Glasgow artist Harrington Mann (private collection), which remains in the family. In March of that year the couple bought two 'large' paintings by E. A. Hornel and David Gauld from Alexander Reid and, two months later, a picture by Thaulow..$^{\circ}$ Entries in the Reid stock books are often lacking in detail and it is difficult to identify specific works, but one of these early purchases was almost certainly Hornel's unusually large canvas Spring of 1903, which was photographed hanging on the landing in the Workmans' house in Seamore Place in 1921 (Fig. 2)..$^{31}$ Typical of Edwardian taste, as well as Hornel's highly decorative mature style, it features six little girls playing in a woodland setting. It may have appealed to Elizabeth, herself one of six children, and already a young mother of two baby girls.

Just before the war the couple turned to William Orpen and William Nicholson, acquiring a 'Bouddha' by Orpen, most likely Still Life with Porcelain Chinese Figure of 1908 (private collection), in 1917, and Nicholson's The Grey Shawel of 1910 (private collection) the following year. ${ }^{32}$ They were also among the earliest supporters of the avant-garde group known as the Scottish Colourists, especially S. J. Peploe, F. C. B. Cadell, and Leslie

30 Alex Reid Daybook 1899-19o9, London, Tate Archive, TGA 2002/11/250.

$3^{1}$ 'Interior Domestic Architecture', Academy Architecture and Architectural Review, 53 (1921), 25-44 (p. 41).

$3^{2}$ The Nicholson was bought in 1918 for $£_{275}$. See Reid Daybook 1913-20, TGA 2002/11/279. 


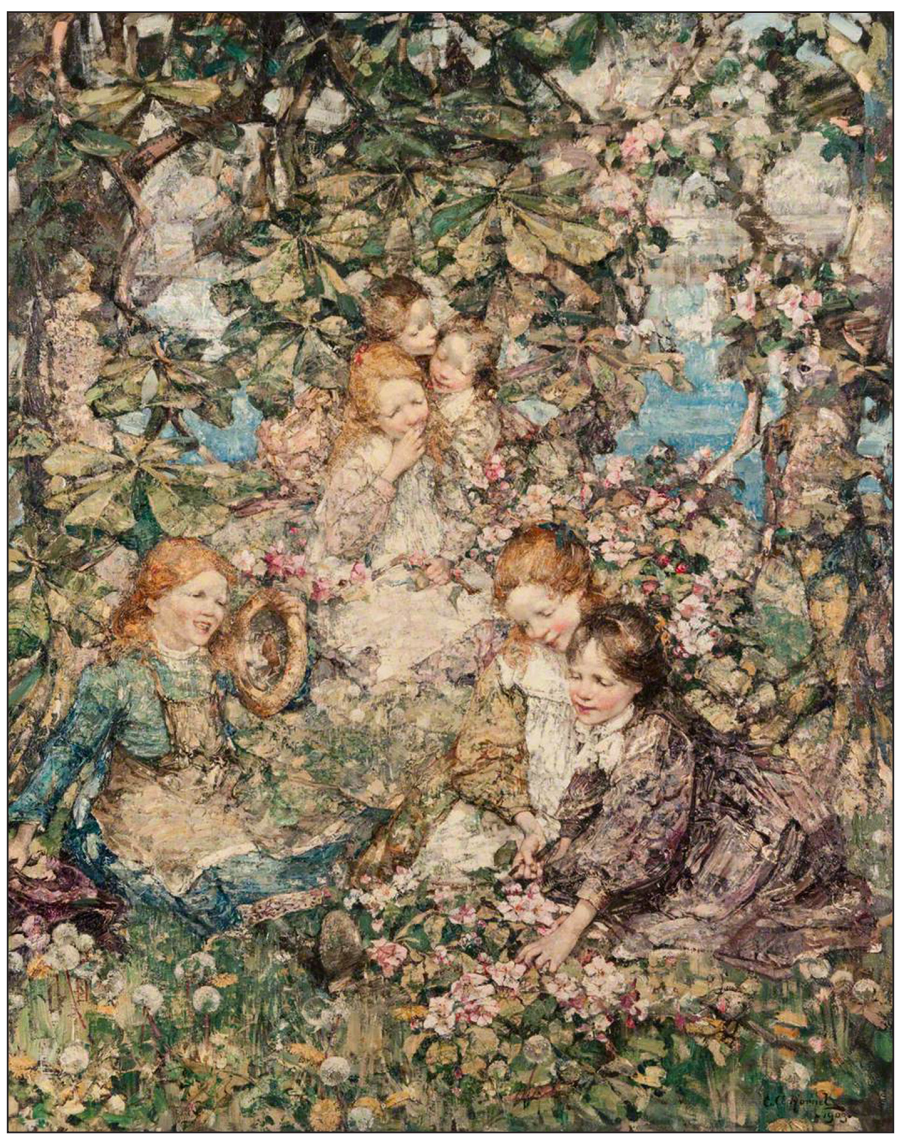

Fig. 2: Edward Atkinson Hornel, Spring, 1903, oil on canvas, $152 \times 122.5 \mathrm{~cm}$, McLean Museum and Art Gallery. Gift from the Trustees of the Stuart Anderson Caird Bequest 1930, 1977.893.

Hunter. All three artists were included in the sale of Elizabeth's collection in December 1929, along with pictures by Thaulow, Nicholson, James Guthrie, Alexander Roche, W. Y. Macgregor, Hornel, Henry, Stuart Park, and Robert Burns. 33 The only part of the Scottish collection that McNeill Reid attributed solely to Robert was the important collection of works by the Scottish Impressionist William McTaggart, many of which hung in the

33 See sale catalogue, Modern Pictures \& Watercolour Drawings, The Property of Mrs $R$. A. Workman, Christie's, London, Friday, 6 December 1929. It included works by Albert Besnard, Frank Brangwyn, Robert Burns, F. C. B. Cadell, George Clausen, James Guthrie, James Whitelaw Hamilton, Joseph Henderson, George Henry, E. A. Hornel, Leslie Hunter, Augustus John, D. S. MacColl, W. Y. Macgregor, Henry Muhrman, A. J. Munnings, William Nicholson, Stuart Park, S. J. Peploe, Alexander Roche, Henri Le Sidaner, Lucien Simon, Robert Macaulay Stevenson, Frits Thaulow, and William Wells. Advertisement, Bystander, 16 December 1931, p. 569 . 
dining room at Seamore Place, with North Wind, Kilbrannen Sound of 1883 taking pride of place above the mantelpiece (Fig. 3). ${ }^{34}$

In summary, therefore, McTaggart aside, the bulk of the Workmans' Scottish pictures, up until the First World War, were acquired jointly, while the French pictures were purchased by Elizabeth, albeit on Robert's account. Thereafter, and certainly after 1923, most purchases were made in Elizabeth's name, at the Lefèvre Gallery in London. From that date, as we shall see, Robert was preoccupied by his shipping business and this was also the period when Reid and Lefèvre were working as unofficial 'partners', making the London gallery a convenient and familiar location. Even after 1923, however, correspondence with dealers was still conducted predominantly by Robert, similar to the arrangement with Bertha and Potter Palmer.

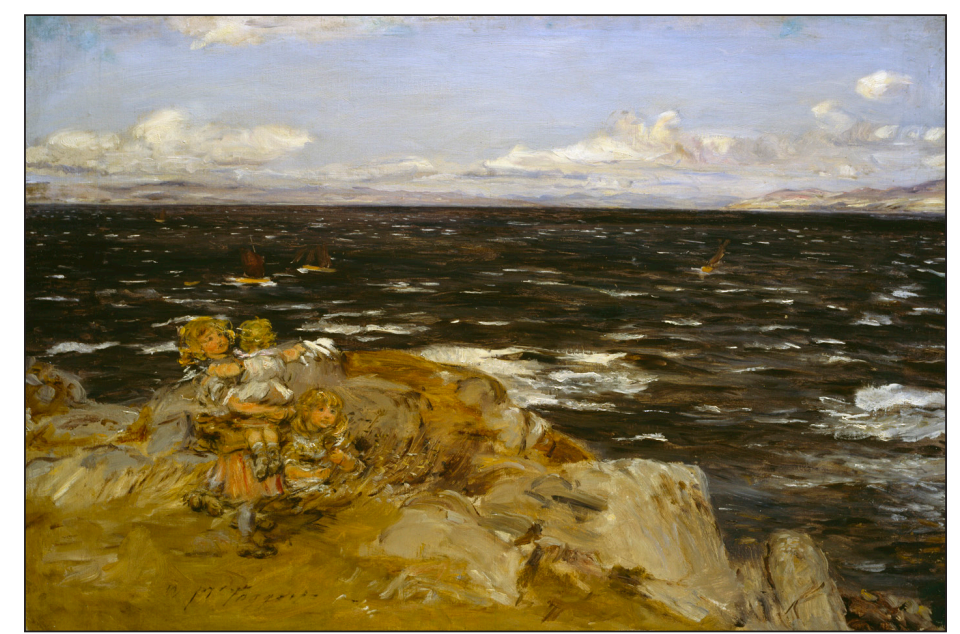

Fig. 3: William McTaggart, North Wind, Kilbrannen Sound, 1883, oil on canvas, $81.3 \times 121.9 \mathrm{~cm}$, Glasgow Museums. Bequeathed by William McInnes, 1944, 2407.

34 'Interior Domestic Architecture', Academy Architecture and Architectural Review, 53 (1921), p. 43. The first recorded purchases through Reid were two watercolours by McTaggart (January 1906) and the first oil, Running for Shelter (City Art Centre, Edinburgh). Workman later acquired Harvest Moon (c. 1899, Tate), 28 Nov 1917; The Storm (1883, Kirkcaldy Art Galleries), 7 Feb 1919, £1500; Dark Blue Sea (probably North Wind, Kilbrannen Sound), 7 Feb 1919, £1250; School in Arran, £50o, and The Bathers, £40oo. See Reid Daybook 1913-20, TGA 2002/11/279. In December $193^{1}$ the McTaggarts were sold through Curtis \& Henson, London in Elizabeth's name. The sale of Elizabeth's collection at Christie's the following year included five McTaggarts: Harvest Moon, Winter, Broomieknowe, Salmon Fisher's Family, A Highland Burn, and A School in Arran. See Christie's sale catalogue, British \& Continental Schools, Property of John Drinkwater Esq \& Mrs $R$ A Workman, Friday, 6 May 1932, lots 6o-64. 
In one of very few surviving letters, written to the French dealer Paul Rosenberg in 1924, Robert makes a clear reference to Courbet's The Trellis of 1862 (Toledo Museum of Art), as belonging to Elizabeth. 35 In fact, there is evidence of her taking an interest in French art as early as May 1915, when she acquired a painting of roses by Henri Fantin-Latour, possibly the very beautiful work of 1891 now in the National Museum of Ancient Art, Lisbon, which was certainly in her collection by 1924. Fantin-Latour was hugely popular with Reid's clients, including industrialists such as David W. T. Cargill and William McInnes, who would go on to establish important collections of Impressionist and modern French art. Reid was fortunate in being able to source good quality works through the dealer Jean Tempelaere in Paris, with the result that Elizabeth went on to build up an outstanding group of paintings, including highlights such as La Table Garnie (1866, Calouste Gulbenkian Museum, Lisbon) and the Scene from Tannhäuser (1864, Los Angeles County Museum of Art). ${ }^{36}$

McNeill Reid dates Elizabeth's first purchase of a work by Degas to 1916 but there is no evidence of this in the Reid stock books (McNeill Reid 1953). We do know that she owned Dancers (1879, Tacoma Art Museum, Washington), a delicate Degas fan painting on silk, and in October 1918 she bought Degas's L'Étoile - Danseuse à pointe (1878-80, Norton Simon Museum, Pasadena), an enchanting work in gouache and pastel on paper, for $£_{2250}$. On the same occasion she acquired a still life by Leslie Hunter and two works by F. C. B. Cadell on her husband's account for only £145, giving an indication of the different market value of modern French and contemporary Scottish art at that date. Unusually, she also bought two items on her own account: a still life by Abraham van Beyeren and 'an antique gentleman's wardrobe', giving her address as Red Tower, Helensburgh. ${ }^{37}$ This is the first instance before 1923 of the couple operating separate accounts, apart from a brief mention of Elizabeth's address as 12 University Gardens in March 1910..38

In the summer of 1919 Elizabeth acquired a small oil study by the American painter James McNeill Whistler entitled Note in Red: The Siesta (1884, Terra Foundation for American Art) for £975 (Reid Daybook 191320). Like the Degas ballet pictures, this was a collector's piece, exquisite and expensive, but bought for close study and contemplation, not

35 Letter from Robert Workman to Paul Rosenberg, 13 May 1924, New York, MoMA, Paul Rosenberg Archive. (I am grateful to MaryKate Cleary for alerting me to the Rosenberg-Workman correspondence.) Elizabeth acquired this work from the collection of the mezzo-soprano Blanche Marchesi.

${ }^{36}$ Fowle, Van Gogh's Troin, p. 97. Elizabeth's collection of Fantin-Latours was sold at Christie's on 9 May 1924; the Tannhäuser to Eugene Cremetti for 1200 guineas.

37 Reid Daybook 1913-20, TGA 2002/11/280. The explanation for this entry is unclear, unless Elizabeth was buying a gift specifically for her husband.

$3^{8}$ Reid Daybook 1910-12, TGA 2002/11/277. There is no mention of any purchase. 
for reasons of status. Nevertheless, McNeill Reid saw an opportunity to exploit Elizabeth's interest in modern French art and in the same year he travelled to Paris to familiarize himself with dealers such as Rosenberg, Étienne Bignou, and the Galeries Barbazanges, all of whom operated in and around the rue La Boëtie in the heart of the city. Here he was able to source good examples of Impressionist and post-Impressionist art and, in time, pictures by Picasso, Matisse, and others. In September of the same year he sold Elizabeth, for $£ 1800$, a Renoir still life, Roses et Cherrefeuilles (c. 188o, State Hermitage Museum, St Petersburg), as a perfect complement to the Fantin-Latours. ${ }^{39}$

McNeill Reid also brought back a number of works by the Nabis artist Édouard Vuillard, including Matin dans le Verger (19o9-11, Birmingham Museums), which he sold to Elizabeth for $£ 450$. The following year the Alex Reid gallery staged the first in a series of major exhibitions of nineteenth- and twentieth-century French pictures, which were held in Glasgow throughout the decade. The 1920 show comprised no fewer than 171 works, including nineteen pictures by Vuillard. The prices for his works were relatively low compared with the Impressionists and they were popular with Scottish industrialist collectors such as Sir John Richmond, D. W. T. Cargill, and Leonard Gow (Fowle, Van Gogh's Twin, p. 132).

Elizabeth bought two pictures by Vuillard from this exhibition: Landscape - House on Left (1900, Tate), then known as Red Roofs, and The Laden Table (c. 1908, Tate). However, among the most important additions to the collection in 1920 was Degas's 1879 portrait of Diego Martelli, the Florentine art critic (Fig. 4), which she acquired, along with Renoir's Melon et Fleurs of 1883 (private collection) for the impressive sum of 5000 guineas..$^{\circ}$ On the same occasion she bought one of Monet's outstanding modern life images, the Boulevard des Capucines (now in the Nelson Atkins Museum, Kansas) for £1500 and two works by Fantin-Latour, making a total of $£ 8000$ expenditure in a single day (Reid Daybook 1913-20). To put this in context, one of Workman's shipwrights would have expected to earn just over two pounds a week in $1920.4^{1}$

Less than a year later, however, the Workmans had returned at least three of their recent purchases, notably the Monet, the Renoir, and the small Whistler oil study. In January 1921 the Renoir fetched an impressive $£ 3250$ at the London branch of the New York dealer M. Knoedler \& Co, whose American clients had included the Havemeyers, Henry Clay Frick,

39 Reid Daybook 1913-20: '15 Sept [1919] Workman Roses et Nasturtiums £18oo'. No artist's name is given.

${ }_{40}$ Reid Daybook 1913-20, 2 January 1920.

${ }^{41}$ Hansard, HC (series 5), vol. 187, cols $671-3 \mathrm{~W}$ (30 July 1925) <https://api.parliament.uk/historic-hansard/written-answers/1925/jul/30/average-weekly-wages> [accessed 12 September 2020]. 


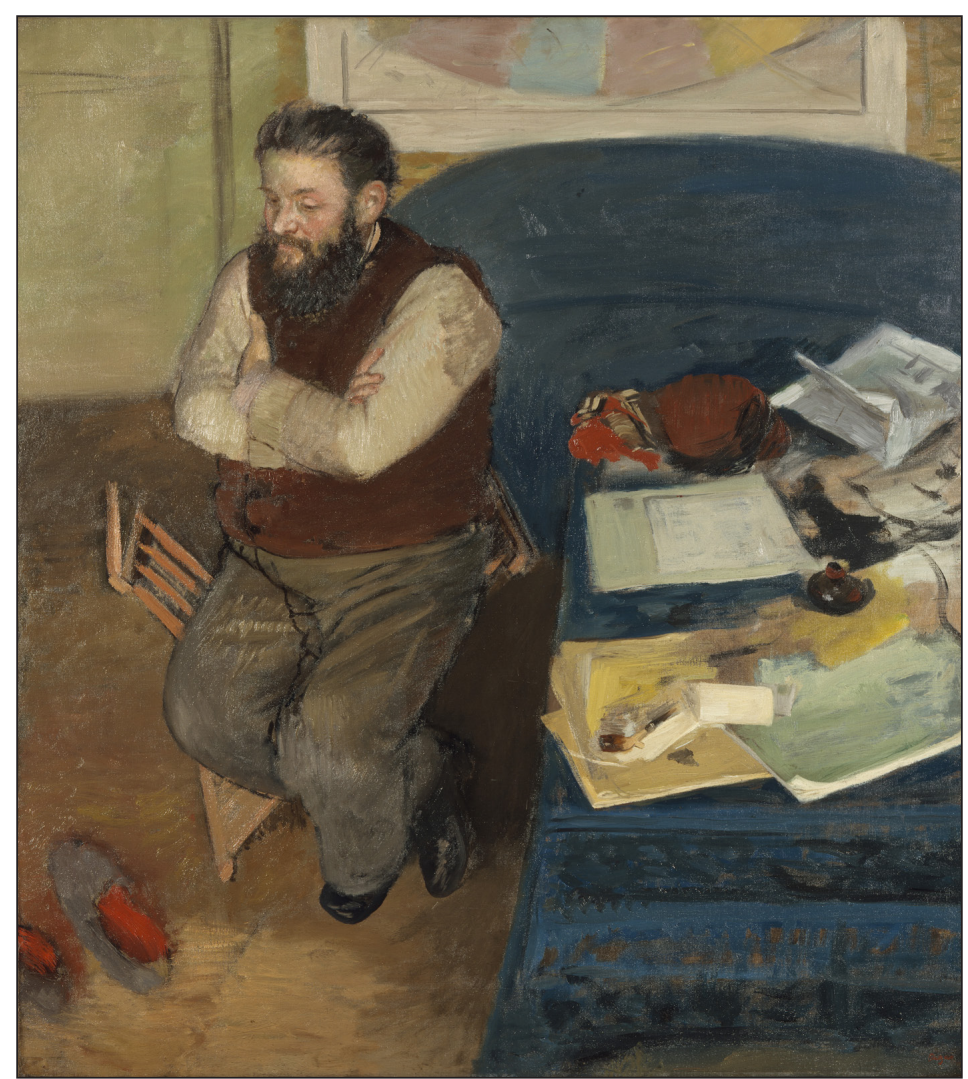

Fig. 4: Edgar Degas, Diego Martelli (1839-1896), 1879, oil on canvas, $110.4 \times 99.8 \mathrm{~cm}$, National Galleries of Scotland, Edinburgh.

and William Rockefeller. The price realized by the still life gives a sense of the inflated price of Renoir's paintings at this time. The artist had died in December 1919 and his works had immediately risen in value, thanks also to the support of critics such as Clive Bell who had praised especially his late work in his book Since Cézanne, published in 1922.

It is possible that Elizabeth had a change of heart about these works, but it might be that the couple were in need of instant liquidity. Even though they both came from comfortable upper-middle-class backgrounds they were now moving in the higher echelons of London society. By 1920 Robert occupied a prominent position in the world of ship owning. He was chairman of several shipping companies, notably the Northumberland Shipbuilding Company, and had also acquired the family company Messrs Workman, Clark of Belfast, which had a reputation for building innovative transatlantic liners. The company was at its peak in the early 1920s, when it was valued at $£_{7}$ million. In keeping with their rising status, the couple moved, in 1921, to 3 Seamore Place, Park Lane, one of London's most 
exclusive addresses. The architects Hepworth and Wornum redesigned the elegant interior, which the Workmans furnished with fifteenth- and sixteenth-century stained glass, Chippendale and Hepplewhite furniture, Dresden and Chelsea porcelain, and their collection of modern pictures. ${ }^{42}$ Such a synthesis of the old and the new created the impression not only of a collection acquired over several generations, but also of an eclectic, deliberately aesthetic and ahistorical interior. William Burrell, too, chose to combine medieval furnishings, china, and glass with modern paintings; while Courtauld hung his modern French paintings in an eighteenth-century interior, creating a fusion between the connoisseurial 'man of taste' and the modern collector. 43

Wyndham Lewis gives an indication of the opulent lifestyle that the couple briefly enjoyed at Seamore Place:

With three liveried menservants at lunch incessantly pouring out champagne, from the most sedative caledonian intonations that have ever massaged my ears, one obtained all the advantages of an all-too-brief Lochside holiday. And yet in this mansion there were more exciting things than Highland Cattle, for Mrs Workman (of whom I did an excellent portrait) was one of the only people in England to understand French painting, of which she had some remarkably fine specimens. (p. 229)

In 1921 the Workmans' fashionable new home was featured in Academy Architecture, including a photograph of the billiard room, showing the Degas portrait of Diego Martelli hanging alongside the Vuillard Red Roofs (Fig. 5). ${ }^{44}$ The couple's neighbours were the newspaper tycoon Sir William Berry, later Viscount Camrose, at no. 2, and, at no. 4, the diplomat and Scottish shipping magnate James Mackay, 1st Earl of Inchcape, who was

${ }^{42}$ Alfred de Rothschild had earlier lived at 1 Seamore Place. The houses were later demolished to give Curzon Street direct access to Hyde Park.

43 Andrew Stephenson, "An Anatomy of Taste": Samuel Courtauld and Debates about Art Patronage and Modernism in Britain in the Inter-War Years', in Impressionism for England: Samuel Courtauld as Patron and Collector, ed. by John House (London: Yale University Press, 1994), p. 37. See also Frances Fowle, "Gefährliche Begegnungen und unziemliche Begleiter": Das Sammeln moderner französischer Malerei in Grossbritannien Ende des 19. und Anfang des 20. Jahrhunderts', in Kunst ohne Geschichte: Ästhetisch motiviertes Sammeln in Europa und Amerika', Scripta manent, 1 (Munich: Hirmer, 2014), pp. 81-9o.

44 'Royal Academy Exhibition Review', Academy Architecture and Architecture Review, 52 (1921), 1-32 (pp. 28-29); 'Interior Domestic Architecture', 53 (1921), 25-44 (pp. 39-44); 'Interior Domestic Architecture', 54 (1922), 44-68 (pp. 45-49); 'Garden Architecture', 55 (1923), 57-72 (pp. 62-63). See also Architect, 10 March 1922, p. 173, and 21 December 1923, p. 422. 


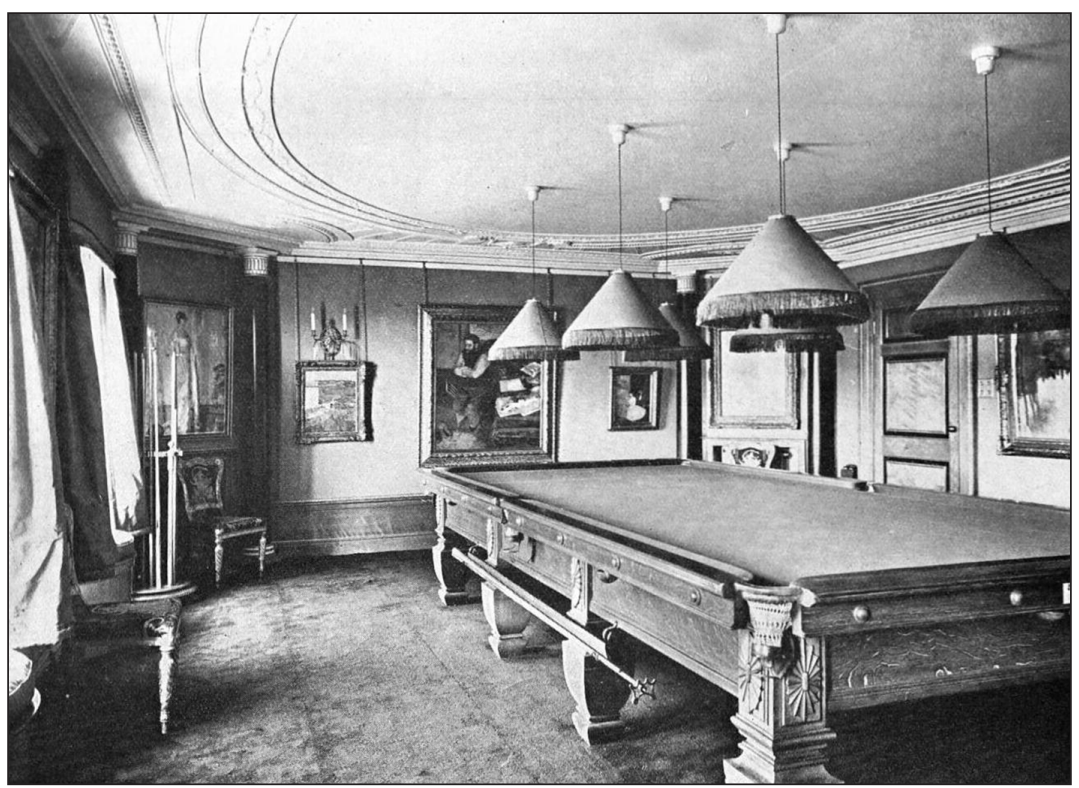

Fig. 5: The Billiard Room, 3 Seamore Place, Park Lane, 'Interior Domestic Architecture', Academy Architecture and Architectural Review, 53 (1921), p. 39. National Library of Scotland.

part of the sailing fraternity. Camrose also sailed and had an important picture collection which featured in Country Life in 1928.45

Sailing, and in particular racing, was also a passion of Elizabeth's. Just after the war she acquired Nyria, a large and sleek racing yacht, designed by Charles Ernest Nicholson. She was soon a regular competitor at the annual regattas at Cowes on the Isle of Wight, on the River Clyde near Glasgow, and at Cultra in Northern Ireland. ${ }^{4}$ In 1923 she made a name for herself by racing against and defeating the King's yacht Britannia at the Cowes Regatta and they raced again during Clyde fortnight. ${ }^{47}$ Yachting is a very physical sport, and there were numerous photographs and articles on Elizabeth and Nyria, highlighting the fact that a woman was so prominent

45 'An $18^{\text {th }}$-Century London House Redecorated: No.2 Seamore Place, Mayfair: The Property of Sir William Berry Bt', Country Life, 18 February 1928, pp. 208-o9.

${ }^{46}$ Elizabeth Workman featured in numerous articles on the annual regattas, especially in 1923. See Belfast News-Letter, 7 July 1923, p. 8; Sketch, 1 August 1923, p. 216; Bystander, 1 August 1923, [n.p.]; Sketch, 15 August 1923, [n.p.]; and 'Women in Sport', Illustrated Sporting and Dramatic News, 18 August 1923, p. 377.

47 'Woman in Sport', p. 377. British Pathé movies featured Nyria and Britannia competing against each other on the Clyde and at Cowes in 1923. See, Over the Waves, 1923 <https://www.britishpathe.com/video/over-the-waves/query/Britannia>; and The Clyde Fortnight, 1923 <https://www.britishpathe.com/video/the-clyde-fortnight> [both accessed 13 September 2020]. 
in such a male-dominated sport..$^{8}$ Elizabeth's extraordinary resilience is illustrated by the fact that she continued sailing even after a car accident in 1922, which left her with a serious back injury and a permanent limp. Undaunted, she insisted on being winched aboard Nyria and strapped down in the hatch area so that she could observe the action at first hand ('Women in Sport', p. 377).

In 1921 and 1922 the Workmans' name disappeared from the Reid \& Lefèvre stock books and it was not until October and November 1923 that there was a renewed flurry of activity, coinciding with an exhibition of postImpressionist art organized by Alex Reid at the Lefèvre Gallery in London. It was also from that autumn onwards that Elizabeth Workman's name was now logged, in place of her husband's. Was Robert strategically transferring certain assets into his wife's name, or was he in fact giving her financial independence while he himself focused on the business, which was taking up more and more of his time? Certainly, from around 1923 onwards, Robert Workman's business suffered a series of setbacks, exacerbated by problems with the supply of steel, as well as by an unstable economy. In September 1923 the share price of the Northumberland Shipbuilding Company dropped so dramatically that there were rumours of forced liquidation. ${ }^{49}$ It is perhaps unsurprising then, that as chairman of a struggling company Robert was not only otherwise preoccupied, but would have been concerned not to be recorded as disposing personal wealth on building up his art collection.

The impact of the slump, if any, on collectors such as Courtauld, whose fortune came from the manufacture of rayon, was not immediately evident, since 1923 was the year in which he began buying pictures in earnest. Nevertheless, McNeill Reid recalled that the London exhibition attracted very few clients:

For the first ten days or so the only sale was a Van Gogh [Oleanders] to Sir Michael Sadler, which he almost immediately cancelled, and we envisaged a complete flop, when a Scottish lady, then resident in London, a Mrs Workman, came in and at one fell swoop bought two Van Goghs, a Lautrec and a Gauguin..$^{\circ}$

Elizabeth's purchases from the Lefèvre exhibition demonstrate not only how advanced she was in her tastes, but also her powers of discernment, since several pictures from her collection are now key works in major international

\footnotetext{
${ }^{4}$ For example, she was on the front page of the special feature on 'Women in Sport', p. 377 .

49 Robert Workman published a statement in the Belfast Neres-Letter on 26 September 1923 .

$5^{\circ}$ Lecture titled 'Art Collecting in Dundee' given by A. J. McNeill Reid to the Art Society in Dundee (1965), property of Professor I. R. C. Batchelor, Broughty Ferry, Dundee.
} 
museum collections. In addition to two still lifes by Henri Marchand she bought two outstanding works by Gauguin - Martinique Landscape of 1887 (Fig. 6) and the 1889 Portrait of Meyer de Haan (Metropolitan Museum of Art) - as well as Toulouse-Lautrec's Fane Avril Leaving the Moulin Rouge (1892, Wadsworth Atheneum). ${ }^{5^{1}}$ She also, in 1924, acquired Van Gogh's The Bridge at Trinquetaille (1888, private collection), followed by the rejected Oleanders (1888) (Fig. 7) (McNeill Reid 1953). Recorded prices varied from $£ 800$ to $£ 1650$, and so she was not obviously being forced by her husband to make economies. Indeed, around the same period she added

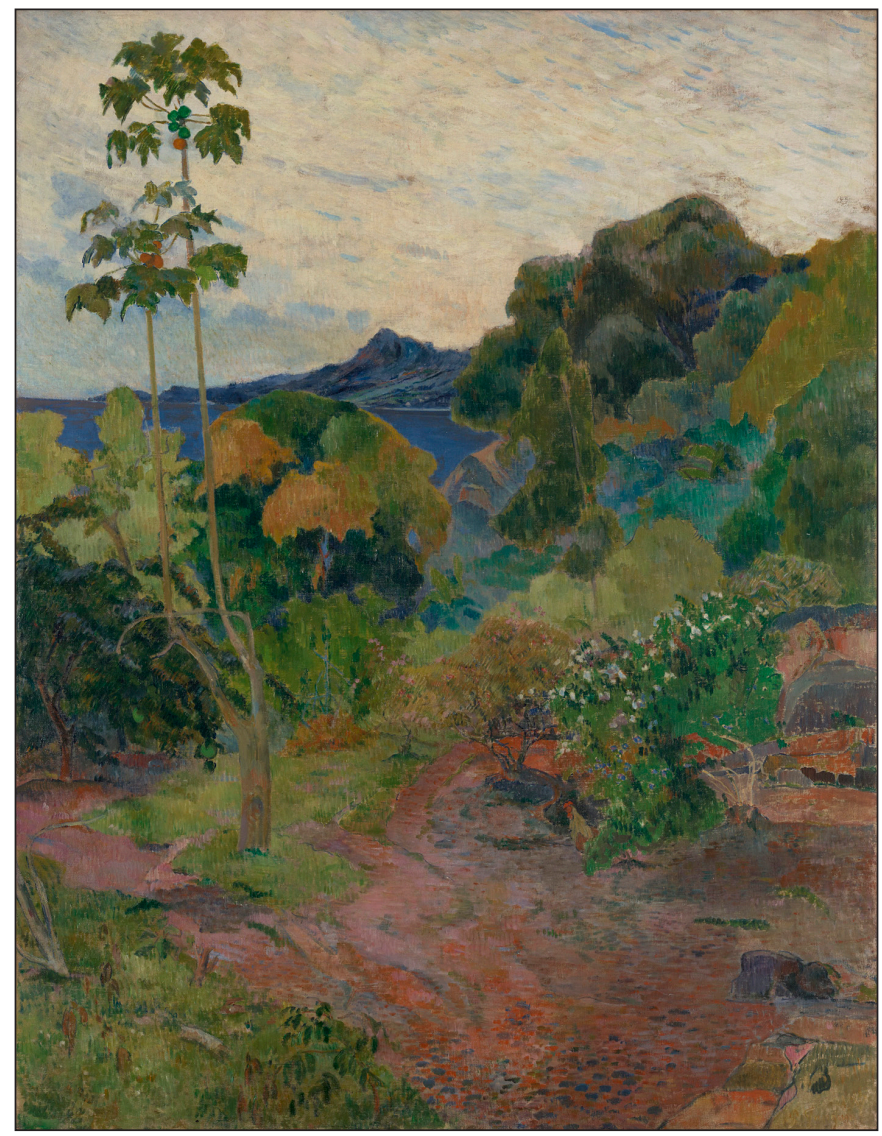

Fig. 6: Paul Gauguin, Martinique Landscape, 1887 , oil on canvas, $117 \times 89.8 \mathrm{~cm}$, National Galleries of Scotland, Edinburgh. Presented by Sir Alexander Maitland in memory of his wife Rosalind 1960.

${ }_{51}$ The entry in the Reid Daybook 1920-25, TGA 2002/11/275 is as follows: ' 26 Nov 1923 (Mrs Workman) 3 Oil paintings No. 3735 "Meyer de Haan" by Paul Gauguin $£ 8$ oo; No. 3736 "Paysage Exotique" by Paul Gauguin £1650; No. 3734 "Jeanne d'Avril" by H. de Toulouse-Lautrec £1050.' 


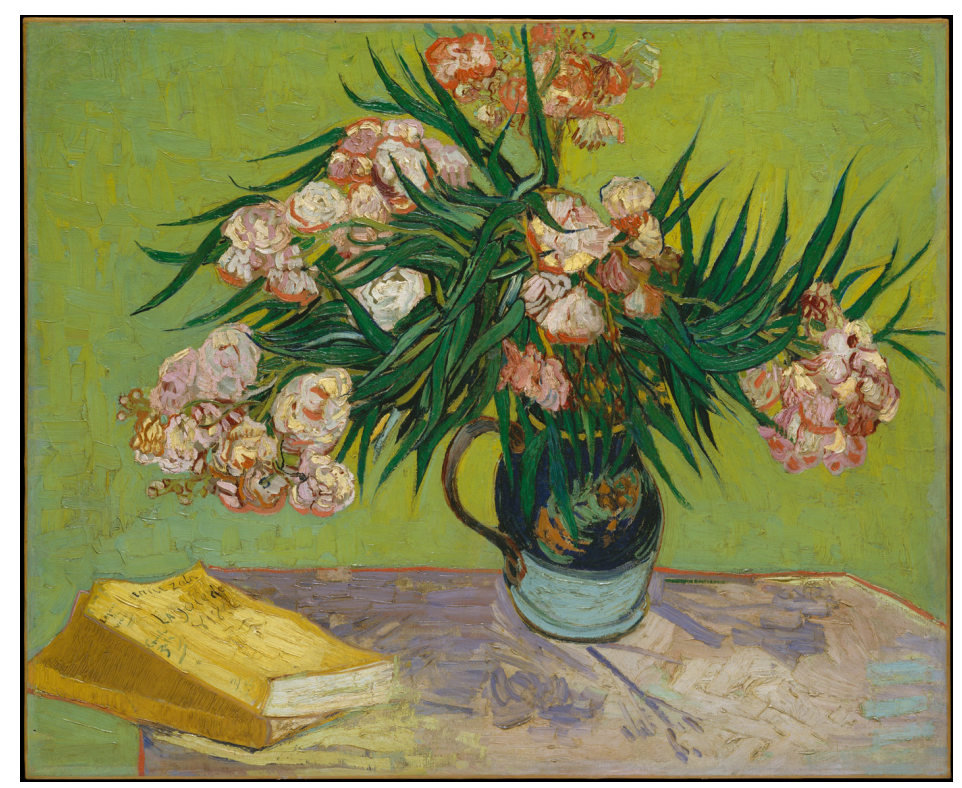

Fig. 7: Vincent Van Gogh, Oleanders, 1888, oil on canvas, $60.3 \times 73.7 \mathrm{~cm}$, Metropolitan Museum of Art, New York. Gift of Mr and Mrs John L. Loeb, $1962,62.24$.

Gauguin's Symbolist Self-Portrait with Halo and Snake (National Gallery of Art, Washington DC) and a third Van Gogh, Ward in the Hospital at Arles (1889, Oskar Rheinhart Foundation).

To put these purchases in context, Courtauld bought just one work by Toulouse-Lautrec from the Lefèvre exhibition. In comparison to Elizabeth he was slow to develop a taste for Van Gogh and, although he bought Gauguin's Martinique Landscape when she was forced to sell it in 1928, he soon returned it. Influenced by Roger Fry, he did, however, acquire an outstanding group of works by Cézanne, but he failed to extend his collection, as Elizabeth was to do, beyond the post-Impressionists.

Unsurprisingly, other dealers besides Reid and Lefèvre made approaches to the Workmans, among them Paul Rosenberg in Paris. Rosenberg was one of the foremost French dealers and had made important sales to American clients such as Albert C. Barnes in Philadelphia and Arthur and Georgette Sachs (of the Goldman Sachs dynasty). He was also beginning to penetrate the London market, working in tandem with Reid and Lefèvre. In April 1924 Rosenberg sent Toulouse-Lautrec's large canvas At the Cirque Fernando (1887-88, Art Institute of Chicago) to the Workmans on approval. However, presumably on account of Robert's financial situation, the couple were in need of capital and Elizabeth had agreed to sell her entire collection of paintings by Fantin-Latour. Robert wrote to Rosenberg: 'We have made up our minds not to purchase any further works of art until 
we see how our sale of Fantins results. ${ }^{52}$ Unfortunately, the pictures sold for three to four thousand pounds below their estimate and Elizabeth was unable to afford the painting. Robert reported to Rosenberg: 'We are not disposed at the moment to buy any further works unless she [Elizabeth] sells the Courbet flower picture [The Trellis] at a good price.'53 Despite the tone of Workman's correspondence with Rosenberg, and the couple's apparent need for liquidity, Elizabeth continued to buy good quality Impressionist pictures, including works by Manet and Monet. ${ }^{54}$ Was her husband unable to control her extravagance, or was their personal financial situation in fact less serious than Robert had indicated to Rosenberg?

By late 1924 Elizabeth was becoming even more daring in her purchases, but she was also able to buy at relatively low prices. In October 1924 McNeill Reid included five Matisse paintings in a large exhibition of modern French art which opened in Glasgow and moved to the Lefèvre Gallery in London the following month. The exhibition included works by Derain, Othon Friesz, Dufy, and Vlaminck, three works by Georges Rouault, and three by Braque and Picasso. P. G. Konody wrote the preface to the catalogue and when the show moved to London he reviewed it for the Observer, commenting that it was the most significant exhibition to be shown in the capital since Roger Fry's groundbreaking exhibitions of 1910 and 1912:

Not since the memorable first two post-Impressionist exhibitions at the Grafton Galleries has London had a chance of seeing so representative a collection of independent contemporary French paintings as the one which now fills the Lefèvre Galleries in King Street, St James's. 55

Fry visited the exhibition and reviewed it very favourably. He was amused by Konody, 'ex-watch dog of foreign heresies and denouncer of morbid tendencies, roaring as gently as any sucking dove over the merits of Picasso, Derain, Friesz and Matisse'..$^{6}$

Once again Elizabeth was the main buyer at the exhibition, demonstrating that her taste was already far in advance of Courtauld or any other

${ }^{52}$ Letter from Robert Workman to Rosenberg, 24 April 1924, Paul Rosenberg Archive.

53 Letter from Robert Workman to Rosenberg, 13 May 1924, Paul Rosenberg Archive.

54 On 16 May 1924, for example, she acquired Manet's Peonies (1864-65, Metropolitan Museum of Art) for £2500 and, two weeks later, Monet's Antibes, Vue des fardins de la Salis (1888, Amalia Lacroze de Fortabat, Buenos Aires) from Alex Reid for £1450. 55 P. G. Konody, 'Art and Artists: French Post-Impressionists', Observer, 16 November $1924,[$ n.p.].

${ }_{56}^{6}$ Roger Fry, 'French Pictures at the Lefèvre Galleries', Nation, 29 November 1924, [n.p.]. 
British collector of the period. As McNeill Reid later recalled, despite the presence in Glasgow of major clients such as Burrell, Cargill, Richmond, Gow, and William McInnes, all of whom were beginning to take a serious interest in modern French painting, the exhibition there was commercially unsuccessful: 'Almost without exception, the collectors of the West of Scotland proved timorous and the pictures went back to London.'57 Elizabeth, by contrast, acquired seven pictures, all for astonishingly low prices and including Matisse's The Closed Window (1918-19, Virginia Museum of Fine Arts, Richmond) and Le Canapé Rouge (1919, Barnes Foundation, Philadelphia), acquired for $£_{355}$ and $£_{270}$, respectively. She also bought her first Picasso, Child with a Dove (1901, Qatar Museums) for $£ 450$, as well as Dufresne's The Rape of Europa (National Galleries of Scotland) for £400 and pictures by Derain, Braque, and Utrillo for $£ 175$ each (Reid Daybook 1920-25).

In 1926 the Workman collection featured in an article by J. B. Manson for Apollo. The article included works that are not listed in the Reid stock books, such as Sisley's Le Bords du Loing à St Mammès of 1885 (private collection) and a Redon pastel of flowers, presumably bought elsewhere. Manson commented in particular on the absence of Cézanne, an artist championed by Fry and so well represented in the Courtauld collection. However, he also observed that the collector of modern art

must have almost the mind of an artist $[\ldots]$, must be deeply responsive to the meaning and expression of modern art $[\ldots]$, must be aware of life itself and have a similar independence of vision $[\ldots]$, not merely accepting what fashion says is acceptable. (Manson, p. 139)

As Wyndham Lewis and McNeill Reid later confirmed, it was Elizabeth, rather than Robert, who possessed such 'independence of vision' and she continued to expand her collection of modern art over the next two years, acquiring works by Raoul Dufy, Maurice Utrillo, Modigliani, Paul Klee, Fernand Léger, Amédée Ozenfant, Léon Bakst, Jean Lurçat, and André Beaudin, as well as further masterpieces by Matisse..$^{8}$ Among the most boldly modern purchases was Matisse's The Windshield of 1917, now in the Cleveland Museum (Fig. 8). In November 1928 the Paris dealer Étienne Bignou (previously director of Reid \& Lefèvre) persuaded her to lend many of her best pictures, including works by Matisse and Picasso, to a large exhibition entitled 'A Century of French Painting', organized by Knoedler at their New York branch, 14 East 57th Street.

57 'Glasgow's Lost Chances: French Picture Bargains City Rejected of Great Value Today', Evening News (Glasgow), 8 January 1930, [n.p.].

${ }_{5}^{8}$ These works and more are listed in the Curtis \& Hanson sale catalogue (third day's sale), 23 December 1931. 


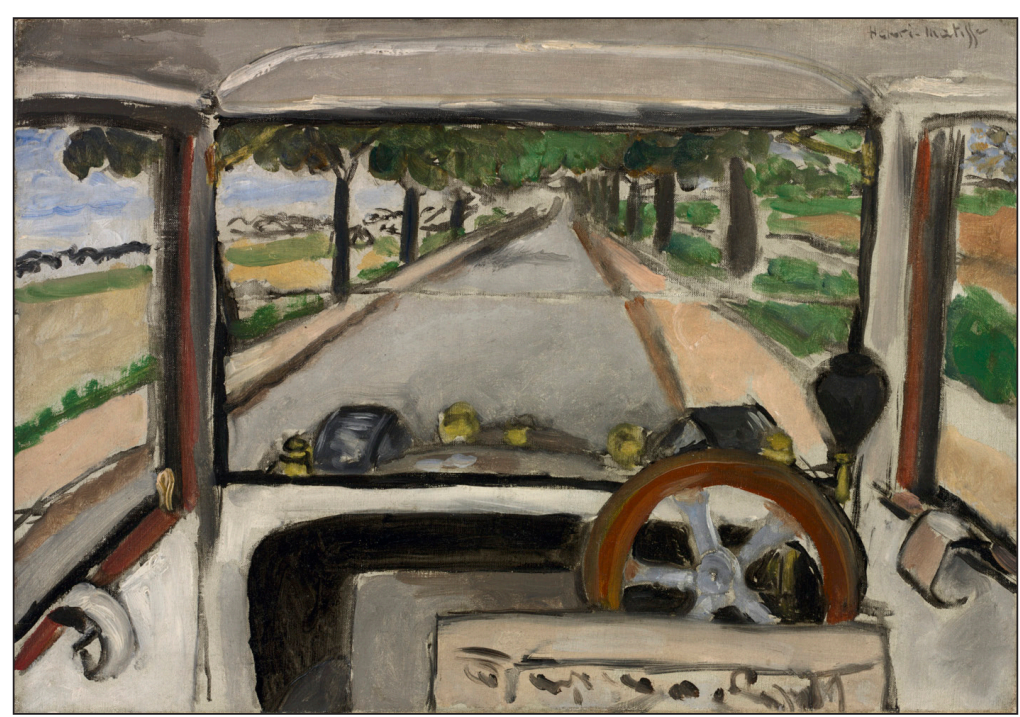

Fig. 8: Henri Matisse, The Windshield, On the Road to Villacoublay, 1917, oil on canvas, $38.2 \times 55.2 \mathrm{~cm}$, Cleveland Museum. Bequest of Lucia McCurdy McBride in memory of John Harris McBride II 1972.225. (C) Succession H. Matisse/Artists Rights Society (ARS), New York.

The Knoedler exhibition is the only indication of Elizabeth Workman's potentially philanthropic intentions. It was also to be the first and only occasion on which her collection enjoyed truly international exposure. From 1926 onwards, shipbuilding, like many industries in Britain, had been suffering from the worsening economic downturn and in 1928 Robert's family company, Messrs Workman, Clark of Belfast, liquidated its assets, changed its name to Workman, Clark and merged with the Northumberland Shipbuilding Company.59 The value of the company was slashed by twothirds, with the result that Robert Workman not only suffered financial loss himself, but was sued by some of his shareholders.

As a result, Elizabeth was forced to sell Nyria, and eventually Seamore Place as well as much of the collection. Many of the British and some French pictures were sold at Christie's on 6 December 1929. The eighteenth-century furniture and porcelain, the stained glass, and most of the modern French pictures and the collection of William McTaggart paintings were auctioned off in a sale conducted by Curtis \& Henson at Seamore Place on 21, 22, and 23 December 1931. Everything was sold in Elizabeth's name, indicating that, even if some of the objects had been acquired jointly or even by Robert himself, he now preferred his own finances to be separated from those of his wife. Clearly, many of the modern French works failed to

59 'The Workman, Clark Case', Belfast Neres-Letter, 11 June 1929, [n.p.]. 
sell and the following year a further sale of pictures by Dufy, Bakst, Léger, Lurçat, and others was held at Christie's. ${ }^{60}$ In the same year the National Galleries of Scotland acquired the portrait of Diego Martelli, one of the nation's earliest purchases of Impressionist art. By contrast, Glasgow's Kelvingrove Art Gallery turned down the opportunity to buy works by Gauguin and Utrillo, much to the irritation of McNeill Reid. A report in the Glasgow Evening Newes, following an interview with the dealer, bewailed the fact that 'the Corporation and its advisors have turned a deaf ear and a blind eye to the movement represented by French Modernism' ('Glasgow's Lost Chances').

In 1935 Robert's company finally went into receivership and the couple retired to Gothic Lodge on Hayling Island, where they spent the rest of their days in relatively quiet seclusion. Elizabeth continued to buy and sell art before the Second World War, acquiring further works by Dufy and Lurçat, which she was offered at a reduced rate by Reid \& Lefèvre, since the Workmans were 'such good friends' of the dealer and 'among [Lurçat's] very earliest supporters' ${ }^{61}$ Just as many wives participated in their husband's art collecting, Robert was a continuous support to Elizabeth, both emotionally and financially. After his death in 1948 she ceased collecting and devoted herself to her children and grandchildren.

This article has aimed to provide an insight into one of Britain's unknown collectors and to offer a glimpse of a lifestyle that was all too transient. Over the centuries art collections like Elizabeth Workman's have been dispersed, and the collector has been forgotten. In certain cases, as here, this was caused by economic change and upheaval; such was the fate, for example, of the Scottish collector James Duncan's collection, sold in the mid-188os in order to shore up a failing sugar refining business (Fowle, Impressionism and Scotland, p. 129). Rarely, however, was a woman collector obliged to sell her collection in order to save her spouse's business. We remember collectors such as Barnes, Burrell, and Courtauld because they enshrined their collections in museums that were memorials to themselves as well as the works of art they acquired. Even women collectors such as Bertha Palmer and the Davies sisters are celebrated, because they left their collections to major museums. Others have faded from memory when their collection was broken up due to de-accessioning; such was the fate, for example, of Lillie P. Bliss's important bequest to MoMA. A true

6o Sale catalogue, British \& Continental Schools, Property of John Drinkwater Esq \& Mrs R. A. Workman, Christie's, London, Friday, 6 May 1932.

${ }^{61}$ Letter from Reid \& Lefèvre to Robert Workman, 1 April 1936. See also letters dated 4 April 1936, 1 May 1936, and 2 May 1936 (the last two to and from Elizabeth Workman) concerning this transaction. There are also two letters dated 24 April 1935 from Reid \& Lefèvre written separately to Elizabeth and Robert Workman, concerning the sale of one of Elizabeth's Modigliani drawings (at a loss) for only $£_{15}$. All letters in the Tate Archive. 
philanthropist, Lillie understood the importance of allowing museums to capitalize on changing tastes and fluctuating markets. Louisine Havemeyer, by contrast, insisted that her own collection remain intact, with the result that her role as a collector has been researched in far greater depth. Nevertheless, like Bertha Palmer and Elizabeth Workman, or later collectors, such as Rosalind Maitland, her story is inextricably entangled with that of her husband. Married to prominent businessmen or industrialists, they relied on their husbands to provide the income for their purchases, and it was his name that was listed in the majority of transactions. As we have seen, despite the ubiquity of her husband's name in the Reid stock books, Elizabeth Workman built up major parts of the collection independently of her husband, albeit with his support.

In other cases, such as that of the Davies sisters in Wales, or Anne Kessler in England, the role of women collectors has been undermined by that of their agent or adviser (in Kessler's case, her uncle, Frank Stoop). By contrast, until very recently, male collectors such as Courtauld or Burrell have been credited with an independence of taste that ignores the role of the dealer and fails to take into account the key contribution of their wives. Indeed, only in the last decade or so has scholarship begun to shed a new light on the pioneering role of such women. Even more recently, thanks to the upsurge of interest in collecting and art market history, some of the more invisible figures, like Elizabeth Workman, are being rediscovered. Nevertheless, the reconstruction of such 'lost' collections not only entails painstaking research, it relies on access to dealer stock books and sale catalogues, as well as a broad understanding of the wider social context. Although we have a few tantalizing photographs of the interior at Seamore Place, without receipts and other correspondence the full scale and extent of Elizabeth's collection, the role of her husband, and her motives for collecting can never be fully appreciated. Nevertheless, as Manson remarked in 1926, there is no doubt that Elizabeth Workman possessed a remarkable 'independence of vision' and she deserves to be recognized as one of the most innovative and advanced collectors of modern French art of the early twentieth century. 